\title{
Coral Cover, Zonation and Diversity on Reef Slopes of Chagos Atolls, and Population Structures of the Major Species
}

\author{
C. R. C. Sheppard \\ Department of Natural Science, Sunderland Museum, Tyne \& Wear SR1 1PP, United Kingdom
}

\begin{abstract}
Substrate cover by corals, soft corals, sand, bare rock and algae was determined by several means for seaward reef slopes of the Central Indian Ocean atolls of Peros Banhos and Salomon, Chagos Archipelago, and in the lagoon of the former. Cover of hard substrate by coelenterates averages $80 \%$ between 3 and $42 \mathrm{~m}$, and calcareous algae dominate above and below these depths. Alcyonarian corals contribute about $15 \%$ of this between 3 and $23 \mathrm{~m}$; at least $5 \%$ of rock at all sites is uncolonised. A quantitative method identifies species zones to $45 \mathrm{~m}$ in detail and to $60 \mathrm{~m}$ more briefly on seaward slopes, and to $25 \mathrm{~m}$ on lagoon reef slopes and knolls. On seaward slopes one typical pattern of zones exists of several species and one 'indominant' zone. Different typical zonations exist on the lagoon reef slopes and on knolls. Exceptions to typical zones are recorded. Species richness increases with depth on both seaward and lagoonal slopes to a peak at $20 \mathrm{~m}$ after which a steady decline occurs. The diversity curve on seaward slopes results from two overlapping species associations. Species richness has no general correlation with coral cover, or with species zones. Size-frequency histograms are drawn for 8 densely crowded and 5 more dispersed coral populations. The former and 2 of the latter show bimodal distributions; this is interpreted as reflecting a variable growth rate where colonies remain small for variable, sometimes long periods until opportunity allows accelerated growth into the adult canopy or mode. More dispersed species are either bimodal or unimodal with young that grow rapidly immediately. Population structures of zone-forming species reflect intra- rather than interspecific competition for unpartitioned resources, and the canopy structure resembles those of phaeophytes and trees.
\end{abstract}

\section{INTRODUCTION}

The literature on population biology of corals on reef slopes is much smaller than that of the usually larger and more accessible area of the reef flat. Connell (1973) pointed out that most of the work done has been directed towards the role of corals as reef builders with only a little towards understanding their population dynamics, and that of the latter the best was done before 1940. Recently, work in the Indian Ocean has increased (Stoddart and Yonge, 1971) and reef slopes have been examined in the Red Sea (Loya and Slobodkin, 1971), Aldabra (Barnes et al., 1971), Madagascar (Pichon, 1978a), the Maldives (Scheer, 1972) and others. However population ecology has still only been briefly considered, some exceptions being the diversity studies of Loya (1972), the phytosociological approach of Scheer (1978), work on resource partitioning (Porter, 1976), space partitioning (Benayahu and Loya, 1977), on succession (Goren, 1979) and recruitment (Stimson, 1978). Invertebrate and coral associations have been studied, again mostly on the reef flats (e. g. Taylor, 1968; Davies et al., 1971; Rosen, 1971) but also in the deeper sub-littoral (Lang, 1973; Porter, 1974; Sheppard, 1979) where active methods of aggression and competition have been recognised in addition to the abiotic regulatory factors.

This work is a study of several aspects of coral distribution, diversity and population ecology made during an 8 month visit to Peros Banhos and Salomon atolls in the North of the Chagos Archipelago. Three main lines of study were: (1) Coral cover and definition of coral zones to $45 \mathrm{~m}$ in detail and $60 \mathrm{~m}$ in brief on seaward slopes of both atolls and to the lagoon floor in Peros Banhos; (2) diversity with depth, both within and outside the coral zones; (3) population structures and densities of selected species, particularly the zoneforming and 'canopy' species.

(1) Studies of coral cover, as with many aspects of coral research have been carried out mostly in shallow water. On the reef slope photography has permitted more lengthy but less detailed study of an environment where time is restricted. A method of Drew (1977) was used in Aldahrd (Rarnes et al., 1971) to provide rough 
estimates of cover, and Bellamy (1979) has illustrated part of a reef slope photomosaic. Photography was employed in this study to provide cover data that otherwise could not be obtained.

The naming of species zones to provide a visual reference on the reef or to denote the most important species has frequently been done (Yonge, 1963; Stoddart, 1973). However, the species named is usually that which is relatively most conspicuous (Goreau, 1959a) and no absolute criteria for naming zones have been defined, though Loya (1972) has used cluster analysis to aid and confirm description. For comparison between areas of reef with different abundances and sizes of coral colonies a standardised criterium is needed and suggested in this study, conducted between depths of 2 to $45 \mathrm{~m}$. Outside this range water turbulence or limited observation time restricted estimates of zonal patterns to visual data. Corals of shallow water beyond the algal ridge have been little studied. At the deeper extreme more information is available. In the Atlantic Ocean an Agaricia community exists between 40 and $70 \mathrm{~m}$ (Goreau and Hartman, 1963) while in Bikini in the Indo-Pacific Ocean, Wells (1954) defined an Echinophyllia zone between 18 and $91 \mathrm{~m}$. In Chagos, Dinesen (1977) - using collected specimens - defined a zone of Echinophyllia, Mycedium, Pachyseris and Leptoseris between 27 and $45 \mathrm{~m}$ i similar corals led Pichon (1978a) to name a comparable depth region in Madagascar the 'Agariciidae and Pectiniidae' zone. Foliaceous corals of these families have been recognised wherever reefs have been studied deep enough, though the species and even the genera may differ.

(2) The few reports of diversity with depth have been summarised by Rosen $(1975,1977)$. Diversity, measured as number of genera, generally declines with increasing depth, but evidence is fragmentary and influenced by incomplete sampling. With more detailed sampling, Loya (1972) found that diversity measured as number of species and the $\mathrm{H}$ index increases with fluctuations to $30 \mathrm{~m}$, and stated that in Jamaica species richness does not decline until $40 \mathrm{~m}$. In Panama (Porter, 1972), diversity increases to $5 \mathrm{~m}$ and remains high until $25 \mathrm{~m}$ after which it declines. Much variation exists therefore and in Chagos diversity profiles were obtained for seaward and lagoonal slopes.

(3) Connell (1973) has pointed out several gaps in coral population ecology; three aspects are studied here - density, size of colonies and growth - and measurements of these attributes are used to provide some fundamental information for corals forming dense zones on seaward and lagoonal slopes. Growth and change of growth rate with age or size was studied from the earliest period of reef research; summaries were given by Goreau (1959b) and Connell (1973); the physiological basis of the process was described by Goreau and Goreau (1959, 1960). Similar methods are being applied to the growth of several species from Chagos (Drew, in preparation). Growth experiments have however largely been conducted on colonies in isolation or in a diverse community; growth in homogenous or monospecific stands has apparently not been reported. The problems inherent in measuring growth rates and ages of colonies can, in part, be circumvented by the use of size-frequency histograms which - though they do not provide absolute ages or growth rates by themselves - provide information on relative rates of growth in a standing crop. They have been used extensively in other fields, but only to a minimal degree in coral work where Loya (1976a) employed them in a study of coral recolonisation following mass mortality. Emphasis is placed on sizefrequency patterns in interpreting coral growth in the dense zones described in this work.

\section{METHODS}

Four types of transect study were undertaken at up to 19 seaward sites spaced evenly around the atolls of Peros Banhos and Salomon, and on approximately the
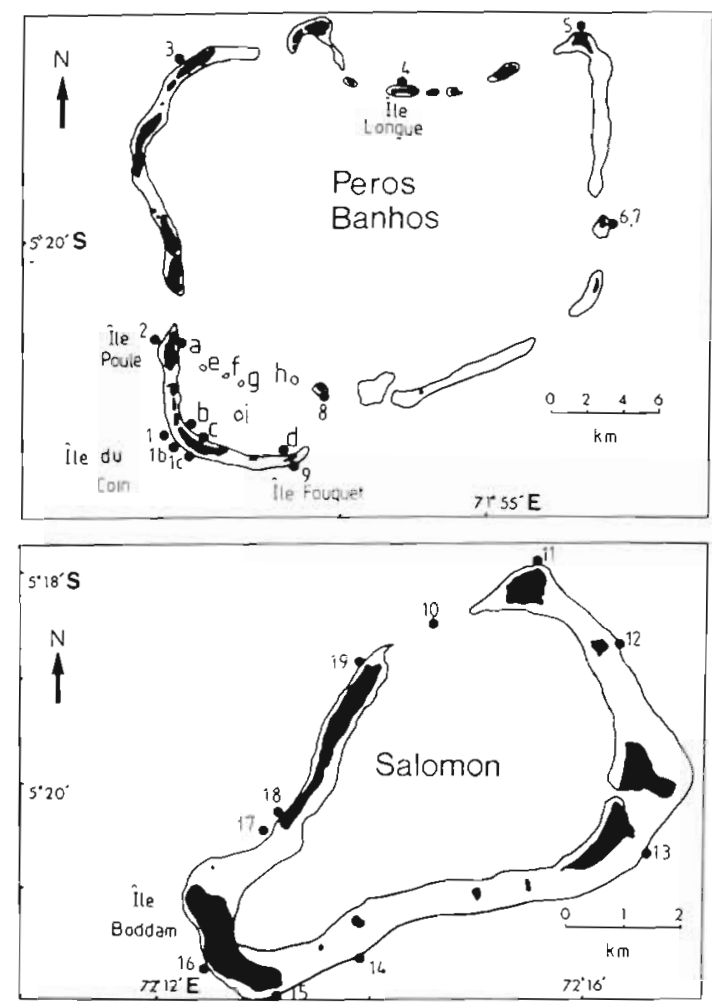

Fig. 1. Locations of transects on Peros Banhos and Salomon Atolls, Chagos Archipelago. Seaward transects are numbered, lagoon transects and knolls lettered. Transect 1 has 3 parts $(1,1 b, 1 c)$ all seaward 
same number of lagoonal slopes in the lagoon of the former (Fig. 1).

The first series were phototransects. Photographs were taken at depth intervals of either 3 or $6 \mathrm{~m}$ between 3 and $45 \mathrm{~m}$ deep. Each was taken perpendicularly to the seabed and included an area of $5 \times 4 \mathrm{~m}$, within which was a $1 \times 1 \mathrm{~m}$ quadrat. From prints the areas were calculated of $\%$ cover by sand, by coral and soft coral and by solid substrate that appeared from the photographs to have no biota.

To complement this, a second series determined the proportion of the apparently uncolonised hard substrate occupied by encrusting calcareous algae. The $\%$ cover was recorded with the aid of a torch that adequately revealed red areas. These included mostly algae and red sponge which were readily distinguished.

A third series termed 'rope transects' were designed to reveal coral zones. A $10 \mathrm{~m}$ rope, marked at $0.5 \mathrm{~m}$ intervals, was laid successively up the reef slopes, commencing from $40 \mathrm{~m}$ deep or more. Substrate type beneath each $0.5 \mathrm{~m}$ mark was recorded; when this was a scleractinian coral its identity was noted. At the top of the rope the depth was recorded; then a partner looped the lower end over and up the reef, the process being repeated into shallow water. Recording was discontinued either at the surface or where wave action prevented further work, or where the reef front became horizontal for a considerable distance and the final zone had been entered.

At four sites (Transects 1, 2, 14 and 17) observations were extended to 50 or $60 \mathrm{~m}$ deep. For practical reasons the rope method was not employed and records of depth coupled with collections were made. All transects were extended into very shallow water but here also visual methods only were used.

The final series were 'collection transects'; corals were collected for identification from the same depth intervals of 3 or $6 \mathrm{~m}$. In Peros Banhos these took two forms, a collection of every species within a $2 \times 2 \mathrm{~m}$ quadrat, followed by a random collection at the same vicinity of as many different species as could be found. At Salomon atoll only random collections were employed.

Population studies employed $6 \times 6 \mathrm{~m}$ rope grids sub-divided into squares of $2 \times 2 \mathrm{~m}$. Within these, colony sizes, densities and area coverage of each colony were determined. Certain simplifications were made: coral colonies were regarded as circular, semicircular, oval, rectangular or hemispherical, and measurements were taken accordingly to provide estimates of the areas covered by the hundreds of colonies involved. Categorisation of these into classes later reduced inaccuracies.

\section{RESULTS}

\section{Coral Cover and Species Zones}

\author{
Cover with Depth
}

From the phototransects the gross pattern of cover to $42 \mathrm{~m}$ was determined. Figure 2 shows the average values for all seaward transects of three types of cover that were readily distinguished: coral + soft coral, sand, and a third category termed 'bare'. The last appeared from photographs to be uncolonised substrate; it is examined later by alternative means. Above a depth of $3 \mathrm{~m}$ coralline red algae, mainly Porolithon sp. provides an increasing cover and is structurally important.

Coral and soft coral is sparse in shallow water but rapidly attains a cover of 50 to $60 \%$. Sand is equally sparse in shallow water but rises steadily with increasing depth. The 'bare' category remains fairly constant throughout. The standard deviations of the means are high, with values often approaching the mean. This reflects the differences between many transects, though these bare no obvious relation to environmental gradients such as exposure, and the mean pattern is important in later interpretation.

The gross patterns illustrated in Figure 2 can be further sub-divided. In Figure 3 the solid line shows the percentage cover of hard substrate by coral + soft coral, estimated directly from Figure 2 to $42 \mathrm{~m}$ by adjusting for substrate covered by sand. Two deeper values were estimated by separate observations on Transects 2 and 17. Cover by coelenterates remains fairly constant at 75 to $85 \%$ between 3 and $42 \mathrm{~m}$, after which it falls rapidly

From results obtained by the rope transects the average proportion of soft coral in the coral + soft coral category was estimated (broken line in Fig. 3). Soft coral, mainly alcyonarians, vary from 10 to $20 \%$ between 3 and $23 \mathrm{~m}$ deep. This average range may vary between transects, though no more refined pattern exists with respect to depth or exposure. On Transects 12 and 14 alcyonarians outnumber scleractinians, but in all cases their presence declines rapidly at less than $3 \mathrm{~m}$ and below $25 \mathrm{~m}$.

The area above the solid line of Figure 3 is thus that proportion of hard substrate occupied by the 'bare' category. This is a combination of dead coral, bare rock and encrusting biota such as algae and sponges which cannot be distinguished from the photographs. Cover values of this from the photographs ranged between 15 to $20 \%$; this compares well with values estimated at 15 to $25 \%$ from rope transects. The algal component of this category was determined with the aid of a torch on Transects 2 and 14 (Fig. 4). Most points are the mean of 


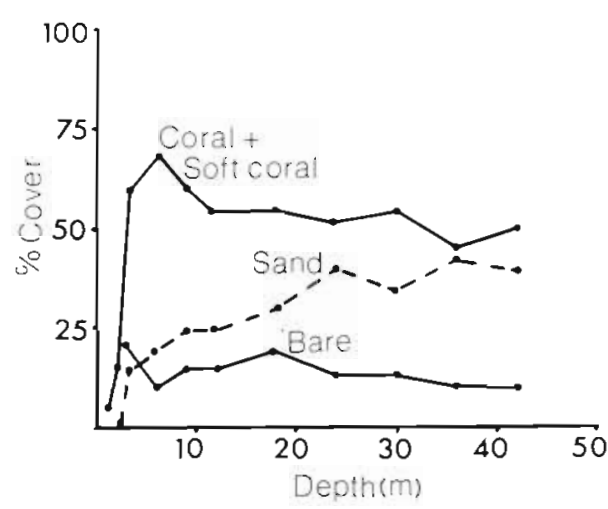

Fig. 2. Depth distribution of three categories of bottom cover identified by phototransects. $s$. $d$. values are up to the value of

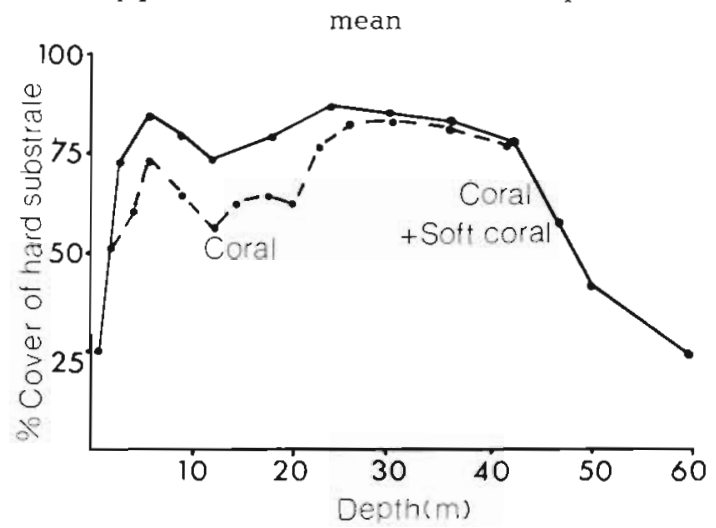

Fig. 3. Depth distribution of cover by coral + soft coral, and by scleractinian coral only. All values expressed as \% of hard substrate cover. s. d. values are up to value of mean

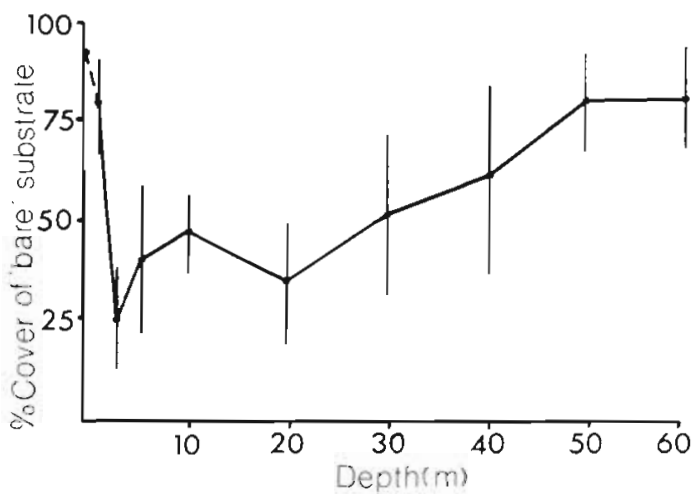

Fig. 4. Depth distribution of cover by red algae, expressed as $\%$ of 'bare' substrate. Vertical bars: standard deviation; $\mathrm{N}=20$

20 readings, 10 from each depth on each transect. The very high proportion of algae in shallow water is attributable to algal spurs and associated coralline algae. In the well-lit region below this to about $30 \mathrm{~m}$ algae are less abundant but increase again in deeper water. Two values - each showing very close agreement - were obtained for each of the 50 and $60 \mathrm{~m}$ depths at which cover is high. The increase in algal cover in deeper water corresponds to the decrease of coral cover. Here, as shown by Goreau (1963) for Jamaican reefs, calcification by corals appears to assume less importance than that of other biota. In Chagos, corals lose their first position to the algae below about $45 \mathrm{~m}$. In shallow water of seaward slopes (to $3 \mathrm{~m}$ deep) they likewise provide less cover than the algae, but are the main group of calcifying organisms between 3 and $45 \mathrm{~m}$ deep.

Lagoon slopes are shorter, extending steeply to $25 \mathrm{~m}$, beyond which the substrate becomes nearly horizontal and largely soft. On all examined knolls (Transects e-h) equal proportions of coral, sand and bare rock exist to their base. Thereafter soft substrate increases at the expense of the other categories though the lagoon floor always contained at least $20 \%$ coral cover to $42 \mathrm{~m}$. Reef slopes adjoining islands differ. These have a similar distribution of cover below $3 \mathrm{~m}$. Above this are shallowing reef flats which contain progressively more bare rock and dead coral. These sites (Transects a-d) show considerable variation near the surface. At all depths large areas of sand whose position was determined by exposure add considerably to the variation of the lagoon reef pattern, making them much less consistent than the knolls.

\section{Species Zones}

Along each rope transect coral records were made beneath every $0.5 \mathrm{~m}$ point. Interpreting what 'beneath a point' means becomes increasingly complex on steeper slopes (Pichon, 1978b). In this study corals recorded were those that either touched a mark or which lay vertically below it. Results from each transect were then divided into $3 \mathrm{~m}$ depth intervals. Only species that occurred in $10 \%$ or more of the records in each depth bracket were retained. This threshold value of $10 \%$ usually included only one species, rarely two, and often excluded all species. Thus the main coral components in terms of cover and the depths at which zones existed were picked out.

Most seaward transects show a great similarity of zonation. Results are shown as an average or typical seaward slope (Fig. 5); exceptions are illustrated beside the typical zones. In shallow water, Acropora humilis is abundant. From 3 to $8 \mathrm{~m}$, A. palifera in its encrusting form dominates, occupying a quarter or more of the points to $10 \mathrm{~m}$. A. reticulata is common over a short span centered on $10 \mathrm{~m}$. Following this in every seaward transect is an extensive region with no dominant coral or species common enough to occupy $10 \%$ of the cover. However, below $25 \mathrm{~m}$ Pachyseris levicollis becomes abundant, reaching a peak at $35 \mathrm{~m}$ and tailing off at $45 \mathrm{~m}$.

Various zones are defined from this. An Acropora 

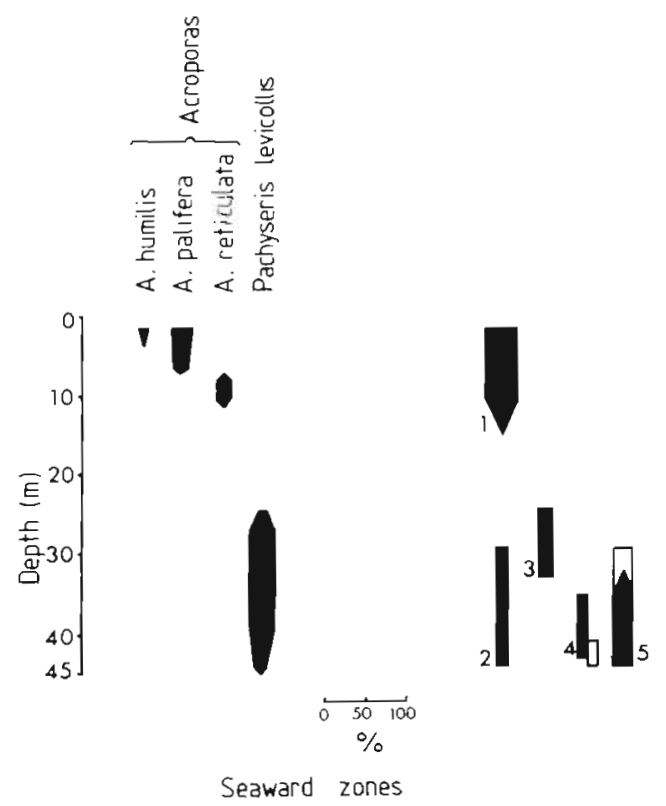

Fig. 5. Species zones on seaward slopes. Typical zones written on figure; exceptions: (1) Heliopora coerulea, Transect 1c; (2) Coscinaraea spp., Transect 1c; (3) Coscinaraea spp., Transects 6,$7 ;$ (4) Leptoseris spp. ( + P. levicollis in unshaded block), Transect 9; (5) Echinopora lamellosa ( + P. levicollis in unshaded block), Transect 4

palifera zone exists from 3 to $8 \mathrm{~m}$. This species coexists with fairly high covers of $A$. humilis at its shallower end and $A$. reticulata at its deeper end. Both are less abundant or extensive than $A$. palifera so that the latter gives its name to the zone. A generic designation would clearly term the 3 to $10 \mathrm{~m}$ region the Acropora zone. From 25 to $45 \mathrm{~m}$, Pachyseris levicollis names the zone. Between the two regions exists one with a much more heterogeneous coral composition and, as is shown later, a high species diversity. This region, from 10 to $25 \mathrm{~m}$, is termed the indominant zone.

The few notable exceptions to this pattern occur mostly in deeper water. Occasionally one of the zone species on an individual transect is below the necessary $10 \%$ to allow the label to apply, though it was never entirely absent. In shallow water one marked exception occurs off Ile du Coin (Transect 1c). Here the octocoral Heliopora coerulea covers 75 to $100 \%$ of the surface to $8 \mathrm{~m}$ deep and remains dominant to $12 \mathrm{~m}$. This zone begins suddenly, developing from a typical transect (1b) to the North with the same exposure, and remains unexplained. The transect has a typical indominant zone, but deeper the small massive form Coscinaraea is very abundant between 25 and $45 \mathrm{~m}$. This zone appears also on the opposite, eastward side of the same atoll (Transects 6 and 7) and in all cases the remainder of the substrate is mostly sand. Two other exceptions occur. In Transect 9, Leptoseris spp. occurs and in the sheltered Transect 4 Echinopora lamellosa replaces Pachyseris levicollis.

Figure 6 illustrates the different zones revealed for (a) knolls and (b) reef slopes. On knolls the typical top surface is characterised by very large colonies of Porites spp.; it is the size of these rather than their large numbers that causes them to be included. Between 7 and $21 \mathrm{~m}$, large table-shaped growths of Acropora spp. dominate, mostly $A$. reticulata but with
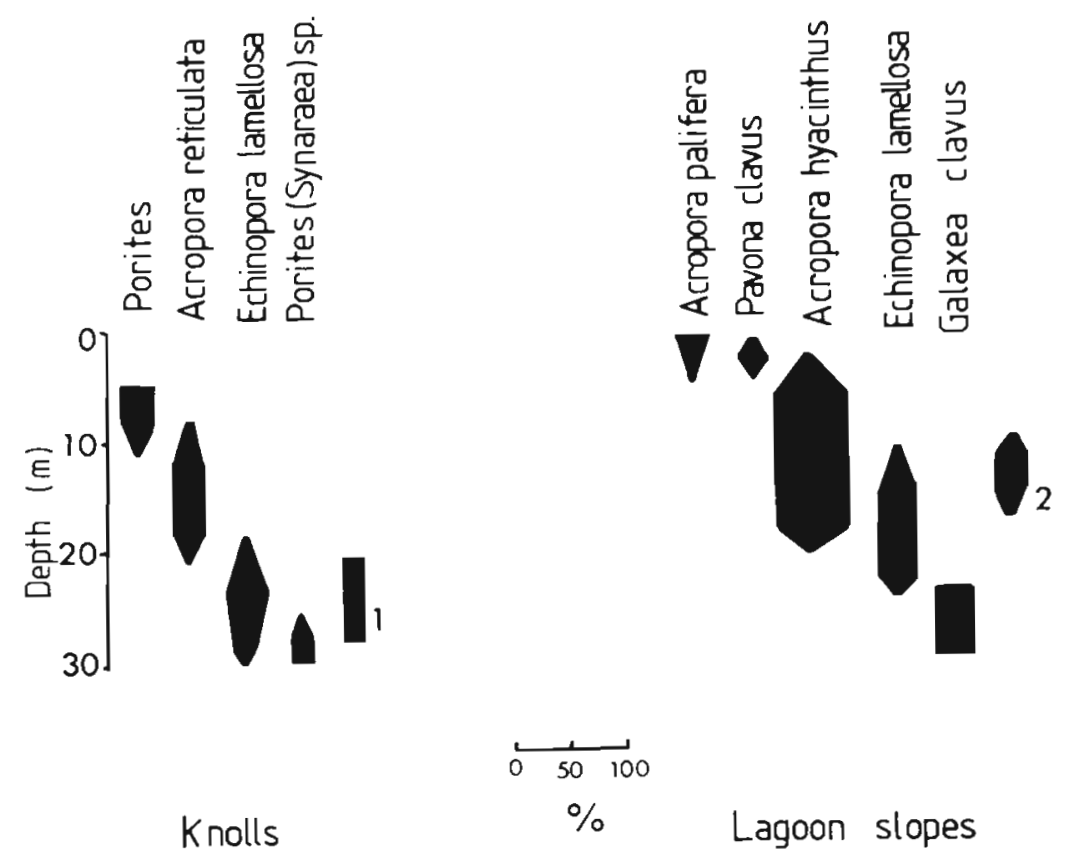

Fig. 6. Species zones on knolls (left) and lagoon slopes (right). Typical zones written on figure; exceptions: (1) Acropora formosa, $\mathrm{N}$ and S sides knoll g; (2) Acropora reticulata, Transects $\mathrm{c}$ and d 
colonies of $A$. cythera and A. clathrata as well. Below this, Echinopora lamellosa always dominates and in some knolis (such as Transecte) it covers the entire substrate. On one profile (Transect g) the branching $A$. formosa dominates large patches of looser substrate and although it characterised this, and would almost always be found on knoll transects, it rarely dominates and is here depicted as an exceptional zone. Likewise Porites (Synaraed) spp. is usually present deeper on the knolls, sometimes sufficiently to be recorded in up to a third of the transect points at around $25 \mathrm{~m}$ or more.

On lagoon slopes adjoining islands, a very dense zone of Acropora hyacinthus covers a span of between 2 or $7 \mathrm{~m}$ to about $15 \mathrm{~m}$, the shallow limit being variable. This species forms the most dense zones of any seen. In more shallow water, Pavona clavus exists in large colonies and Acropora palifera is always present; in Transects a and $\mathrm{c}$ it covers up to $100 \%$ of the substrate. In deeper regions, Echinopora lamellosa generally occurs from 10 or $15 \mathrm{~m}$ which is slightly shallower than on the knolls; this may reflect the more turbid water generally found at the edge of the lagoon. This zone terminates at the foot of the reef slope. Then, on the lagoon floor for at least $1 \mathrm{~km}$ is a cover by foliaceous Galaxea clavus that is highly variable but averages 25 to $50 \%$. The zone of Acropora reticulata is regarded an exception in this group as it occures in only two of the four measured. It is distributed over depths similar to those of the knolls.

\section{Shallow and Deep Zones}

On lagoon reef slopes, rope transects covered the shallowest region. On seaward slopes the shallowest region corresponds to that occupied by the Grooves and Spurs (in preparation) and was too turbulent for this. The prime regulating factor in this region is water movement (for reviews consult 'Marine Ecology' Volume I: RiedI, 1971, 1972). Two main coral communities exist: that where Acropora palifera dominates and that where it is entirely absent, at least to $3 \mathrm{~m}$. The former is the most widespread while the latter is seen only in the

Table 1. Coral species in $0-3 \mathrm{~m}$ on seaward slopes

\begin{tabular}{|cc|}
\hline 1st species & 3rd group \\
Stylophora pistillata & Millepora spp. \\
& Leptastrea transversa \\
2nd group & Pocillopora damicornis \\
Acropora humilis & Pocillopora eydouxi \\
Platygyra daedalea & Heliopora coerulea \\
Favites chinensis & Tubipora musica \\
& Acropora palifera \\
& (either dominates \\
& or is absent)
\end{tabular}
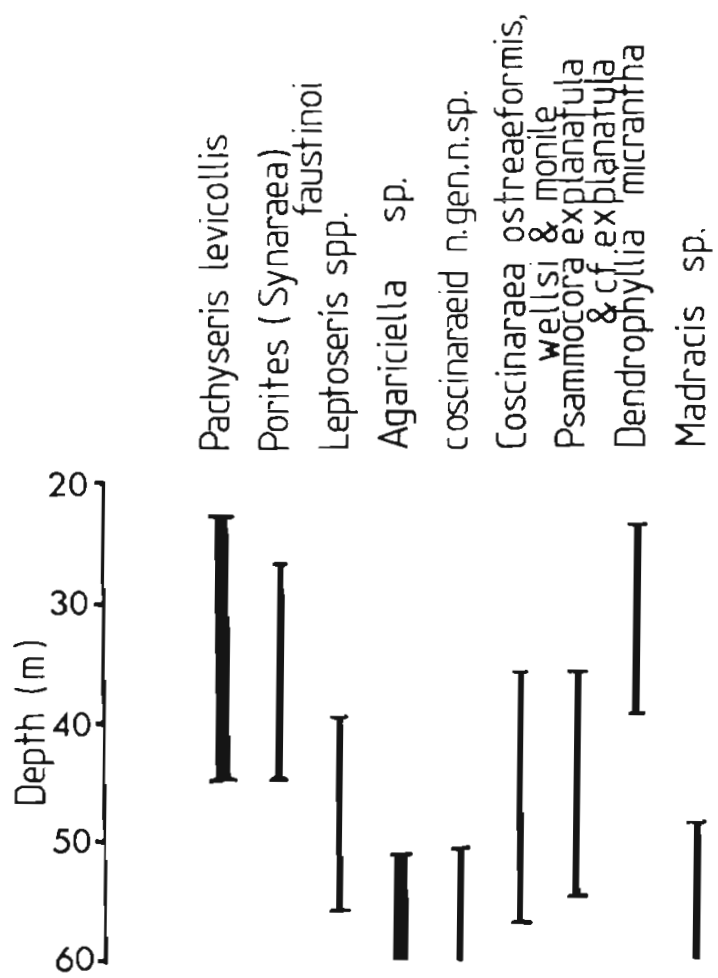

Fig. 7. Distribution of coral species between 20 and $60 \mathrm{~m}$ depth on seaward slopes. Bars: main depth distribution; thick bars: species whose covers exceed $10 \%$ of substrate

most exposed reefs. The nature and order of other species remains similar. Table 1 presents a summarised pattern of shallowest seaward zonation. The first species to appear is always Stylophora pistillata in its stout 'mordax' form, followed by Acropora humilis and others. In most transects, $A$. palifera would then appear and occupy over half the substrate within a few $m_{i}$ this would lead on to the A. palifera zone below the spurs (Fig. 5). Generally, above $3 \mathrm{~m}$ the coral cover is very low and no species could qualify as zone-naming; as the substrate itself is algal the naming of a coral zone would, in any case, not be appropriate.

The study of the deeper region to $60 \mathrm{~m}$ was extended up to $20 \mathrm{~m}$ so that a zone of overlap exists with the rope transects for comparison of methods. Below $30 \mathrm{~m}$, at least 30 species are common, although the large majority are at their lower limits of distribution. Less than 10 are largely or exclusively found in deep water (Fig. 7).

As in the rope transects, Pachyseris levicollis occupies a zone from 25 to $45 \mathrm{~m}$ where it commonly occupies over $50 \%$ of the substrate over extensive areas. Porites (Synaraea) faustinoi co-exists with it and occasionally equals it in cover. Leptoseris is not usually a common genus on Chagos gut grows below $35 \mathrm{~m}$ following on from P. levicollis. Below $50 \mathrm{~m}$ is a very marked zone of Agariciella sp., a foliaceous coral, up to $0.75 \mathrm{~m}$ across. This may occupy up to $30 \%$ of the 
substrate. At the same depths is a coscinaraeid - a new genus with thick leaves of the same size as Agariciella. Here also the ahermatypic Madracis sp. also grows. Other small corals, mostly of Coscinaraea and Psammocora are found between the two zones of leafy corals. Finally, the range of the ahermatypic Dendrophyllia is of note due to its narrow depth range well within the hermatypic limits. Its presence below $40 \mathrm{~m}$ is uncommon in any of the transects in these atolls.

Of these distributions two may be considered as zones comparable with those of shallow water. Pachyseris levicollis, already named in this respect, occupies a zone that terminates at $45 \mathrm{~m}$. Agaricialla sp. designates the zone below $50 \mathrm{~m}$. Other species (Fig. 7) are sometimes common but none occupy even nearly $10 \%$ of the substrate. Therefore, around these two atolls, hermatypic zonation is clear down to at least $60 \mathrm{~m}$.

\section{Coral Diversity with Depth}

Several authors (Loya, 1972; Porter, 1972; Connell, 1978) have suggested that species number is a satisfactory measure of diversity. Because of the greatly increased time needed for other measures that incorporate abundance, species number was applied here and determined for each depth interval on each transect.

On seaward reefs, the values of species number for each depth on all transects are averaged to produce a typical or average diversity profile with depth (Fig. 8). A smooth curve with very small standard errors results, showing a rising diversity to $20 \mathrm{~m}$ and thereafter a fall to $60 \mathrm{~m}$. For most points the number of pooled stations is 16 or more, though the deepest sites involved less. The small standard errors are a reflection of both this number and the uniformity of diversity regardless of the aspect of each transect.

Diversity above $3 \mathrm{~m}$ is low, remaining always in single figures. A sharp rise occurs after $3 \mathrm{~m}$ which continues consistently, though less steeply, to a maximum at $20 \mathrm{~m}$, after which a steady decline occurs. Each transect follows the mean curve closely. How-

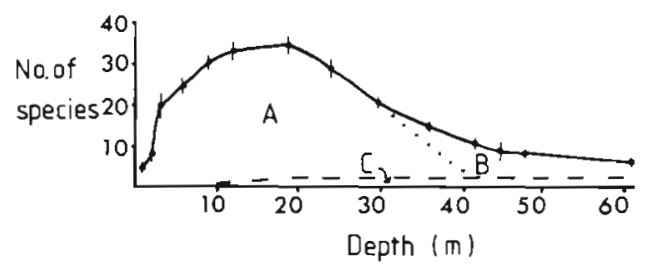

Fig. 8. Number of species as function of depth on typical seaward slope. Values are means; bars indicate standard errors. (A) shallow-water group; (B) deep-water group; (C) ahermatypic group. $\mathrm{N}=16$ for points to $45 \mathrm{~m} ; \mathrm{N}=4$ for deeper points

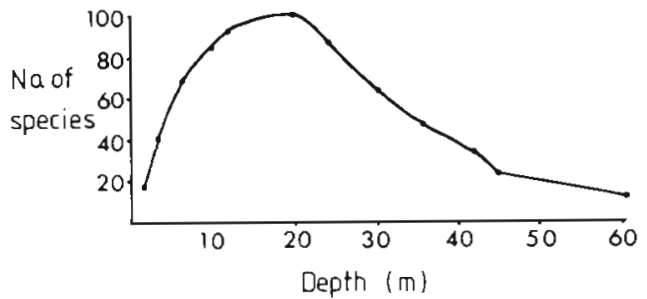

Fig. 9. Total number of species as a function of depth on all seaward slopes

ever, species recorded at each frequently differ although with considerable overlap. A curve showing total records rather than the mean is shown in Figure 9. The total number of species is higher but the curve remains the same.

The high-diversity region between 10 and $25 \mathrm{~m}$ corresponds to the indominant zone. The number of species that occur here declines both shallower and deeper from the peak in a normal distribution curve whose deeper part is shown by a dotted line in Figure 8. These species form a fairly diverse group 'A' (see also Sheppard, in press). Such distribution suggests optimum conditions between 15 and $20 \mathrm{~m}$ for the large majority of species. Deeper, a progressively more important group ' $B$ ' formed of deeper-water corals (Fig. 7) superimposes onto the normal distribution to form an extended tail. Thus species found in the shallow low-diversity region are also found in the main body of the curve; the former is simply a depauperate part of it. In the species-poor region at the deeper end, however, the species are different.

The broken line in Figure 8 indicates ahermatypic species, notably dendrophylliids such as Dendrophyllia and Tubastrea, rhizangiids such as Culicia and caryophylliids such as Paracyathus and Polycyathus. These affect the main curve in a minor way to about $30 \mathrm{~m}$, but thereafter become increasingly important, contributing over a third at $45 \mathrm{~m}$. The drop in hermatypic diversity with depth is thus slightly more rapid than that for total species.

A typical seaward reef profile is a gentle slope to $15 \mathrm{~m}$, becoming steeper to about $40 \mathrm{~m}$ before shelving again into greater depths. The highest diversity is thus on and below the 'drop-off'. It has been reported elsewhere (Loya, 1972; Porter, 1972) that profile affects diversity and possible effects of this were assessed in a limited way. One section of reef (Transect 1) has a uniform slope of less than $5^{\circ}$ to over $45 \mathrm{~m}$, and is bounded to North and South by reef with more normal profiles. Sedimentation appeared to be minimal on both this section and on Transect $1 \mathrm{~b}$. Coral species were recorded from both (Table 2). Apart from one unusually high collection at $36 \mathrm{~m}$ on the former, no marked or general differences exist between them and 
Table 2. Number of species in reef slope with steep central section and adjacent gently sloping profile

\begin{tabular}{|cccccccc}
\hline $\begin{array}{l}\text { Depth (m) } \\
1 \quad 6 \\
\text { Transect 1 }\end{array}$ & 9 & 12 & 18 & 24 & 30 & 36 & 43 \\
(drop-off at $15 \mathrm{~m})$ & & & & & & \\
$7 \quad 21$ & 26 & 32 & 32 & 25 & 19 & 13 & 12 \\
$\begin{array}{c}\text { Transect 1b } \\
\text { (no drop-off) } \\
5 \quad 29\end{array}$ & 31 & - & 30 & 27 & 17 & 22 & 11 \\
\hline
\end{tabular}

no conclusive effect attributable to angle of slope can be determined.

No difference exists between species curves of knolls and lagoon reef slopes; hence the mean curve represents both (Fig. 10). Points between 6 and $18 \mathrm{~m}$ are means from 26 readings. Outside this range, 4 readings provide mean values; that at $40 \mathrm{~m}$ is a single reading. The curve follows the same pattern as that from seaward reefs, showing a peak diversity at $20 \mathrm{~m}$. In deeper regions, however, numbers are slightly greater than at the corresponding seaward point.

These curves resemble some from the Atlantic province (Porter, 1972); the part above $20 \mathrm{~m}$ may correspond to the profile obtained from the Red Sea (Loya, 1972). Most other reported profiles show continuous falls in diversity with depth although most have been measured at the genus rather than at the species level (Wells, 1954; Rosen, 1975, 1977).

Several zones on lagoonal slopes occur at intermediate depths where corals are diverse. On seaward reefs at the same depths species are more evenly distributed. However, evenness is strictly relative. Species/ frequency distributions of many populations follow a log normal curve (Fisher et al., 1943); this was tested for a plot of $108 \mathrm{~m}^{2}$ at 10 to $12 \mathrm{~m}$ on Transect 2 . The results (Fig. 11) show that here too frequency distribution fits the nearly universal pattern. In coral zones however, the primary difference is that the most abundant species are more populous or common although species number remains unaffected. On the seaward plot the commonest species are Porites lutea and Pavona varians, the latter being the species most cer-

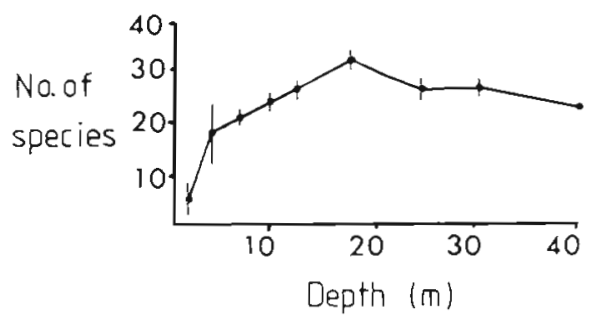

Fig. 10. Number of species as a function of depth on typical lagoonal slope. Values are means; bars indicate standard errors. $N=26$ for points between $6-18 \mathrm{~m} ; \mathrm{N}=4$ at $2 \mathrm{~m}$ and $20-30 \mathrm{~m} ; \mathrm{N}=1$ at $40 \mathrm{~m}$

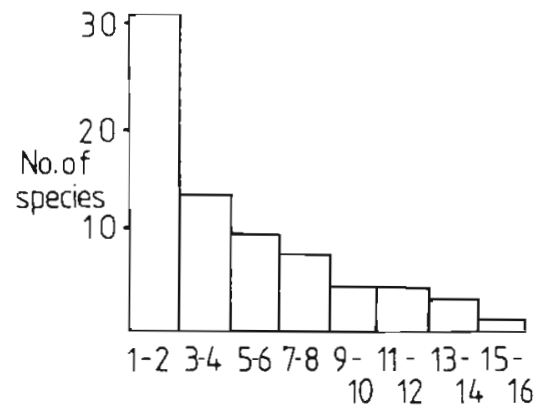

No. of individuals / species

Fig. 11. Frequency-distribution of scleractinian species. Seaward plot on Transect 2

tain to appear in seaward collections between 8 and $25 \mathrm{~m}$. However, neither exceeded the threshold value of $10 \%$ presence; hence in this study do not name a zone. The important difference with species that designate zones is that, as well as being more abundant they form larger colonies; the combination of both results in the higher cover.

No correlation exists between diversity and coral cover, and the increase and then decrease of species numbers takes place against a background of generally unchanging cover.

\section{Densities and Population Dynamics of Zone-Forming Species}

Colony densities of several zone-forming species including juveniles are shown in Table 3. Most average 1.5 to 4 colonies $\mathrm{m}^{-2}$; this depends partly on colony size. Colonies in dense populations must be influenced by other members of their own kind. Several of these species are ramose or foliose and cover much more substrate than they are attached to, forming canopies. This causes shading (Pichon, 1978b) and has parallels with terrestrial botany (Connell, 1978). Canopy forming colonies may influence both the 'understory' corals

Table 3. Densities of main zone-forming coral species

\begin{tabular}{|lccc|}
\hline Species & $\begin{array}{c}\text { Transect and } \\
\text { depth }(\mathrm{m})\end{array}$ & $\begin{array}{c}\text { Density } \\
\text { (colonies } \mathrm{m}^{-2} \text { ) }\end{array}$ \\
\hline Porites lutea & 2 & $(10)$ & 1.86 \\
Lobophyllia corymbosa & 2 & $(6)$ & 1.69 \\
Galaxea clavus & $\mathrm{b}$ & $(23)$ & 1.38 \\
Acropora hyacinthus & $\mathrm{h}$ & $(25)$ & 0.65 \\
& $\mathrm{~b}$ & $(6)$ & 5.88 \\
Echinopora lamellosa & $\mathrm{b}$ & $(4)$ & 8.25 \\
Acropora reticulata & $\mathrm{e}$ & $(24)$ & 2.97 \\
Acropora palifera & $\mathrm{e}$ & $(6)$ & 1.60 \\
& $\mathrm{c}$ & $(1-3)$ & 3.10 \\
Pachyseris levicollis & 2 & $(1-4)$ & 4.35 \\
& 17 & $(25-30)$ & 2.25 \\
\hline
\end{tabular}


by shading and other members of the same species by competing for space and light.

Several populations were measured. Ramose Acropora hyacinthus and $A$. reticulata in the lagoon occupy a negligible fraction of the substrate that they shade. Deeper, the foliose Echinopora lamellosa and Pachyseris levicollis grow on fairly steep slopes and provide a similar canopy effect. Galaxea clavus likewise has extensive concentrations on the lagoon floor. In shallow water Acropora palifera is either encrusting or has stout branches; this coral covers no more substrate than that to which it is attached. Because of time constraints no species was selected below $30 \mathrm{~m}$.

For comparison, four species of lesser density were also measured: Porites lutea from the indominant zone where it was the most abundant species, Lobophyllia corymbosa from lagoon slopes, Stylophora pistillata from the tops of knolls and Ctenella chagius, a medium sized, massive form unique to Chagos, but fairly common.

The horizontal area covered by each colony in a population sample was measured. This was usually straightforward. Problems concerned (1) 'supercolonies' (Pichon, 1978b); here it was not possible to determine whether two neighbours were of similar or different origin; (2) dead areas separating living areas. Both were most often encountered with Acropora hyacinthus and Galaxea clavus. In $G$. clavus the presence of large dead areas required mapping of colonies from a distance before measurement. With $A$. hyacinthus a dense bed of largely semicircular branches projects from a mass of debris and dead branches; occasionally living branches connected by dead material showed a common origin but for many colonies it was not possible to ensure an independent existence. In this case an individual means a living branch supported by dead rock. In terms of the response of the branches to competition, however, independent origin may not be critical. This problem did not arise with the other species

Figure $12 \mathrm{a}-\mathrm{h}$ shows size frequency distributions for species in dense zones, Figure $13 \mathrm{a}-\mathrm{g}$ for those with less or no self crowding. In all cases the abscissa denotes size classes, the ordinate number of colonies in each class in the sample area. Each set of measurements was divided into 9 size classes, each double the area (in $\mathrm{cm}^{2}$ ) of the one before, according to the geometric progression $50 \mathrm{~cm}^{2}, 100 \mathrm{~cm}^{2}, 200 \mathrm{~cm}^{2}$, etc. The largest colony determined the last size class and the data ordered accordingly. For example, in Figure $12 \mathrm{e}$ and $\mathrm{f}$ the largest size classes of Acropora palifera lay in the 6,400 to $12,800 \mathrm{~cm}^{2}$ range so that after division into 9 classes the smallest was $0-50 \mathrm{~cm}^{2}$. The number 9 has no intrinsic significance but was that which provided most information.
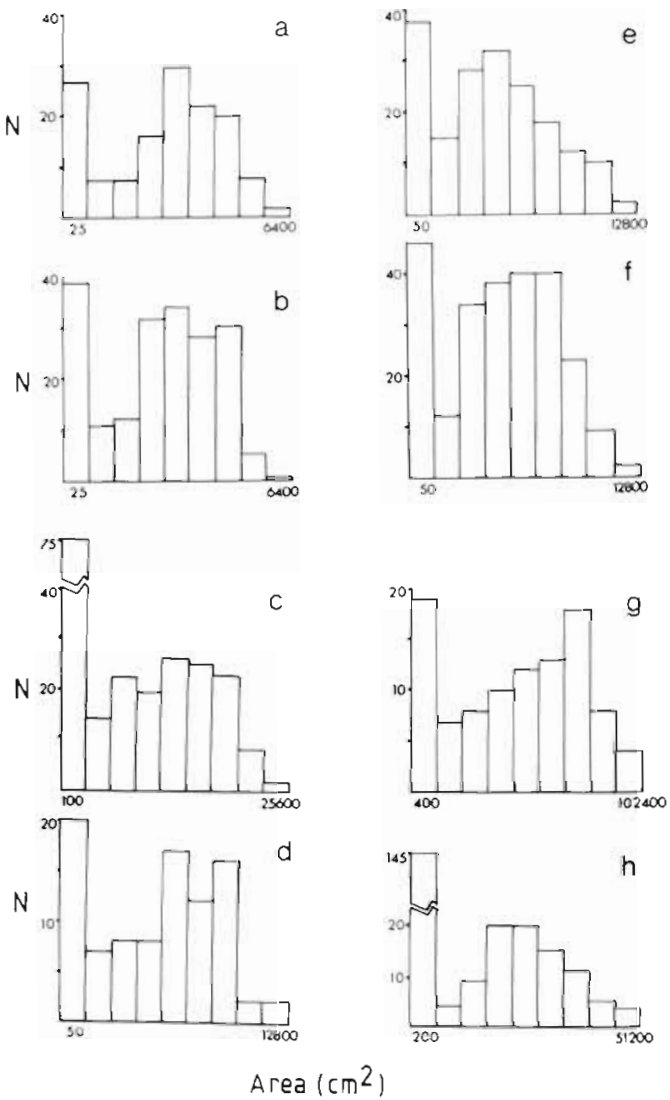

Fig. 12. Size-frequency distribution of species whose presence exceeds $10 \%$ cover. $N$ : number in each size class. For each species data are divided into 9 size classes. (a) Acropora hyacinthus, $300 \mathrm{~m}$ North of Transect b, $6 \mathrm{~m}$; (b) Acropora hyacinthus, Transect b, $4 \mathrm{~m}$; (c) Echinopora lamellosa, Knoll e, $24 \mathrm{~m}$; (d) Pachyseris levicollis, Transect 17, $25 \mathrm{~m}$; (e) Acropora palifera, Transect c, 1-3 m; (f) Acropora palifera, Transect 2, 1-4 m; (g) Galaxea clavus, lagoon floor, Knoll i, 25-30 m; (h) Acropora reticulata, Knoll f, 6-15 m

As pictorial representations, Figures 12 and 13 are influenced by expansion or contraction of the axes. Stylophora, for example, is considered to have a bimodal distribution - although the first mode is low; in this case division into 8 classes might be clearer. However the area under the mode is unchanged provided the geometric progession is retained - as is the interpretation.

All the densely crowded species (Fig. 12) show very similar bimodal population structures. All have high or very high numbers of the smallest size class, much reduced numbers in the next one to three classes and then a second rise and fall. Two interpretations are possible. The first assumes a long spawning periodicity with each peak representing a major period of reproduction. From estimates of growth rates (Wells, 1956; Yonge, 1963; Connell, 1973) it is likely that in this event several years separate each mode and each reproduction period. The similarity between all 

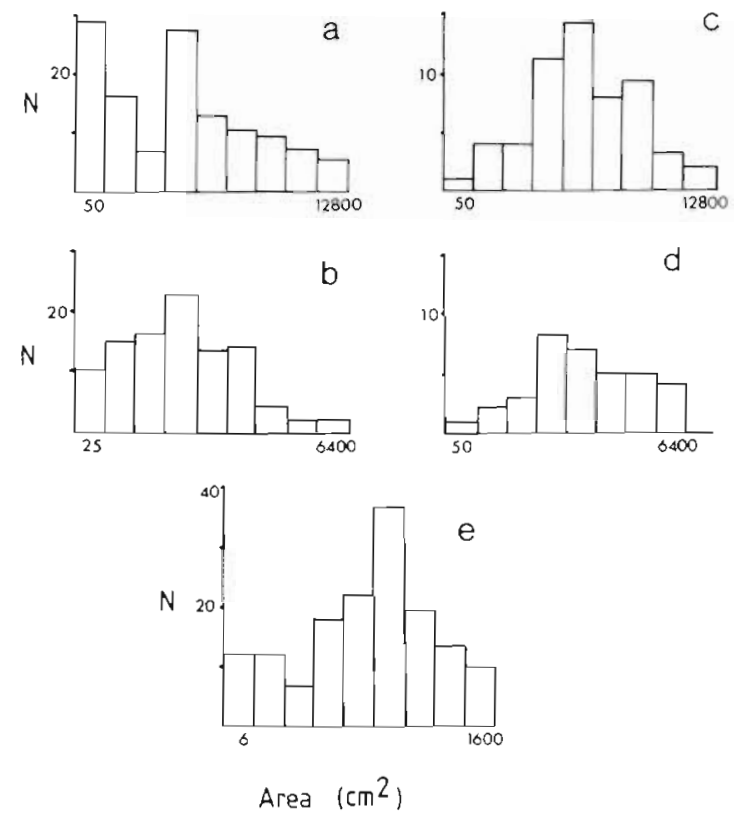

Fig. 13. Size-frequency distribution of selected species whose presence is less than $10 \%$. N numbers in each size class. For each species the data are divided into 9 size classes. (a) Porites lutea, Transect 2, 10-12 $\mathrm{m}_{\mathrm{i}}$ (b) Lobophyllia corymbosa, Transect b, $20 \mathrm{~m}$; (c) Ctenella chagius, Transect e, 10-15 m; (d) Ctenella chagius, Transect 9, 10-15 m; (e) Stylophora pistillata, Knoll e, 3-5 m

species of this group, however, suggests that this is unlikely. The alternative assumes a more even reproduction and settlement but a variable growth rate. In cases of constraints on growth - for example due to space, light or food - young individuals may remain small or grow slowly until better conditions allow growth at an accelerated pace. A dense coral population may respond similarly, the resources in short supply being light, canopy space and possibly zooplankton. All species represented in Figure 12 have colony densities such that individuals crowd each other closely. As with forest trees a prime event of growth in dense coral stands is expansion into the higher canopy. At first a young, small colony remains shaded and small until a gap appears above or around it; then increased illumination and other resources allow a period of faster growth, sending it rapidly from the juvenile to the adult peak. The dip in the curve (second to fourth size classes) may thus be the result of colonies traversing this distance relatively rapidly so that fewer are found here at the period of sampling. Growth in the adult phase then follows a normal distribution. This is readily visualised with the ramose and foliose species but applies as well to Acropora palifera whose colonies closely abutt; the main limiting resourse in this case being space.

Species with lower densities (Fig. 13) show more variation. Three populations - Lobophyllia corymbosa and the seaward and lagoonal populations of Ctenella chagius - exhibit only the normal adult curve. This again is interpretable in two ways: (1) periodic reproduction in which only one peak had occured at the time of sampling; (2) more likely, juveniles exhibit rapid growth immediately with young colonies quickly entering the main mode as they are not constrained by pressure from conspecific adults. There thus never accumulates a peak of young, small corals.

Two other species, not shown to cover even $10 \%$ of the surface, show a response similar to that of the crowded species (Fig. 13a and e). Porites was measured on the seaward reef at $10 \mathrm{~m}$ where it was the commonest species. Although not a dense stand, the colonies were often close enough to touch, and uncolonised substrate was minimal. This represents a state intermediate between the dense stands (Fig. 12) and dispersed species (Fig. 13b-d). The pattern follows that of the former.

Stylophora pistillata was measured on the horizontal top of a knoll, $4 \mathrm{~m}$ deep, where it was abundant but dispersed, and where there was much uncolonised rock. It shows a bimodal pattern and here the general hypothesis whereby crowding prevents initial early growth does not appear to apply. However, other constraints exist at this site, mainly the scouring action by waterboume particles and occasional obliteration by shifting sand. $S$. pistillata is an opportunistic $r$-strategist (Loya, 1976b), whose method of successful maintenance of high population lies in the production of large numbers of young when opportunity exists under hostile conditions. Possibly this explains the large number of small colonies in this population.

\section{DISCUSSION}

\section{Diversity Gradients and Zones}

A common premise is that competition for space on a reef is intense. In some zones of Chagos such as the seaward indominant zone and some lagoonal zones there is a high coverage, but elsewhere much bare rock exists for no obvious reason. Shifting patterns of sand and heavy wave action both cause reductions in some areas but no depth or location existed which had less than $5 \%$ bare rock and usually more. One cause may be difficulty of recruitment due to the remoteness of Chagos, although it is rich in species (Sheppard, in press). In many places on these reefs the suggestion of particularly intense competition for space does not seem very meaningful.

The most densely covered areas are the lagoonal zones whose nearly unbroken canopies look from a 
distance to be almost monospecific. However species numbers follow a rise and fall related to depth apparently independantly of these zones. To seaward the most species rich area corresponds to the indominant zone, but in the lagoon it coincides with the dense covers of Acropora hyacinthus and A. reticulata. Here diversity is raised by numerous species living in gaps in the canopy and on the substrate beneath it which is highly reflecting, allowing sufficient illumination to support the understory. Hence high cover may exist with high diversity, a situation found also in the Caribbean (Porter, 1974); however, equally frequently an inverse relationship has been found (Grigg and Maragos, 1974; Porter, 1974).

The term diversity in many coral studies refers to number of species though sometimes it has involved measures of numbers of individuals as well (Loya, 1972; Porter, 1972). Both may be closely correlated (Connell, 1978). In Chagos the number of species peaks between 15 and $20 \mathrm{~m}$ deep. However where a zone exists the relative numbers of the dominant species may change which will affect a diversity index. For example the index $\alpha$ can be simply determined (Fisher et al., 1943). Values for the seaward indominant zone and for the lagoonal Acropora hyacinthus zone of the same depth are 20 and 6 , respectively, showing that the former area is indeed very diverse and heterogeneous while the same number of species in the latter may be interpreted very differently. The presence or absence of a zone in this study does not affect species number, and the assumed correlation between different diversity measurements may not always be valid.

In both lagoonal and seaward reefs the species rich part is at a depth which is protected from extremes of weather. It is below the shallow area of high turbulence, it has sufficient light and is above the major sedimentation effects in the lagoon or silt-laden upwelling, cold current effects on seaward reefs, each of which are only marked below $30 \mathrm{~m}$. The $20 \mathrm{~m}$ peak therefore appears to be the region of least disturbance.

\section{Zone-Forming Species}

Size-frequency histograms of four species were used by Loya (1976a) to interpret the effects of a very low tide on reef flat recolonisation. Other than this, they have received little attention in corals and bimodal population structures have not been recorded. Yet here the bimodal distribution is universal to the zone forming species and occurs in other populous species as well.

This growth pattern may be due to the effect of competition for space, light and possibly zooplankton.
A substantial first mode indicates plentiful recruitment but the young remain small for a varying and lengthy period until an opportunity such as an opening in the canopy allows an advance into the adult mode. Although attempts were made using Alizarine dye (Lamberts, 1978) to relate growth to size these did not succeed, but in this phase at least correlation of size with age may be very variable. It has been generally found that corals grow proportionately more slowly with age (Tamura and Hada, 1932; Stephenson and Stephenson, 1933; Goreau and Goreau, 1960), but this evidence is fragmentary and inconclusive (Connell, 1973). Most of the corals in the above studies were either isolated or uncrowded by others of their own species. If growth pattern does depend in part on pressure from neighbours the crowding experienced by zone-forming species may influence growth in a way different to that experienced by a species in isolation or in a diverse community. Colony growth may thus show a wider range of size to age relationships and these may be neither steady not regular. Corals calcify in proportion to their illumination to some extent (Goreau, 1959a) and their shapes themselves are partly light determined (Barnes, 1973). A young colony receiving higher illumination beneath a gap in the canopy would be expected to grow more rapidly upwards than one still shaded, and this is reflected in the population structure.

All species in Figure 12 may be considered as canopy species. In these atolls interspecific competition between corals determines to some degree their distribution (Sheppard, 1979). In the dense zones, however, competition pressures differ; the resource partitioning observed in heterogenous communities (Porter, 1976) is less, and individuals compete for the same resources in the same way as their neighbours. Intraspecific competition may be more important than interspecific competition.

This competition is reflected mostly in the morphology of the species and in the nature of the canopies. Growth upwards and outward is necessary to compete successfully for space, light and prey. Apart from Acropora palifera all the zone-forming species are foliose or ramose; massive or other encrusting corals were never designated as zones. Such species have very high surface to volume ratios which is ideal for light capture and is the most economical construction for maximum extension for a given amount of energy.

The coral stands are analogous to some monospecific stands of trees. Horn (1971) distinguishes two extreme geometric distributions of leaves; a 'monolayer' type with dense leaves in a single layer and a 'multilayer' type with leaves scattered less densely in several layers. With high illumination the multilayer configuration is most efficient and permits faster growth while in 
shaded situations the lower part of a multilayer would receive insufficient light and a monolayer is most efficient. In the coral zones both types exist. In well lit water the open latice canopies of Acropora hyacinthus and A. reticulata allow the passage of light which is clearly sufficient to support several lower branches. This has been demonstrated also with large phaeophytes where scattered light in shallow water can support two canopies and an understory (Sheppard et al,. 1978). With A. hyacinthus particularly numerous lower branches develop; in $A$. reticulata lower layers exist less commonly though here branches of other colonies may live below the topmost layer at least until it anastomoses sufficiently to form an unbroken canopy. Zones of both contain high numbers of other species.

Deeper zones are of the foliose species. Echinopora lamellosa, Pachyseris levicollis, Galaxea clavus and those that live deeper still provide unbroken monolayer-type canopies. Beneath these, by contrast, even one which is growing in unusually shallow water, only ahermatypic species can generally be found and these zones do not support high diversities.

Acknowledgements. This work was carried out on the Joint Services Chagos Research Expedition. The numerous sources of financial support are gratefully acknowledged in the Report of the Expedition. Special thanks are due to Anne Sheppard for help with collecting transect data and coral measurements, and to Rod Salm and Holly Arnold for coral collection and sorting. Underwater, Ron Crosby provided invaluable help with unwieldy ropes. Major Peter Ormerod, Sgt. Alan Smith and David Clinch took the phototransects. Most members of the expedition helped with diving and coral collection.

\section{LITERATURE CITED}

Barnes, D. J. (1973). Growth in colonial scleractinians. Bull. mar. Sci. 23: 280-298

Bames, J., Bellamy, D. J., Jones, D. J., Whitton, B., Drew, E. A., Kenyon, L., Lythgoe, J. N., Rosen, B. R. (1971). Morphology and ecology of the reef front of Aldabra. In: Stoddart, D. R., Yonge, C. M. (eds) Regional variation in Indian Ocean coral reefs (Symp. zool. Soc. Lond. 28). Academic Press, London, pp. 87-114

Bellamy, D. J. (1979). Half of paradise, Cassells, London

Benayahu, Y., Loya, Y. (1977). Space partitioning by stony corals soft corals and benthic algae on the coral reefs of the northern Gulf of Eilat (Red Sea). Helgoländer wiss. Meeresunters. 30: 362-382

Connell, J. H. (1973). Population ecology of reef building corals. In: Jones, O. A., Endean, R. (eds) Biology and geology of coral reefs, Vol. 2. Academic Press, London, pp. 205-245

Connell, J. H. (1978). Diversity in tropical rain forests and coral reefs. Science, N. Y 199: 1302-1310

Davies, Spencer P., Stoddart, D. R., Sigee, D. C. (1971). Reef forms of Addu Atoll, Maldive Islands. In: Stoddart, D. R., Yonge, C. M. (eds) Regional variation in Indian Ocean coral reefs (Symp. zool. Soc. Lond. 28). Academic Press, London, pp. 217-259
Dinesen, Z. D. (1977). The coral fauna of the Chagos Archipelago. Proc. 3rd Int. Coral Reef Symp. 1977: 155-161

Drew, E. A. (1977). A photographic survey down the seaward reef front of Aidabra. Atoll Res. Bull. 193: 1-17

Fisher, R. A., Corbett, A. S., Williams, C. B. (1943). The relation between the number of species and the number of individuals in a random sample of an animal population. J. anim. Ecol. 12: 42-58

Goreau, T. F. (1959a). The ecology of Jamaican coral reefs (Species composition and zonation). Ecology 40:67-90

Goreau, T. F. (1959b). The physiology of skeleton formation in corals. I. A method for measuring the rate of calcium deposition by corals under different conditions. Biol. Bull. mar. biol. Lab., Woods Hole 116: 59-75

Goreau, T. F. (1963). Calcium carbonate deposition by coralline algae and corals in relation to their roles as reef builders. Ann. N. Y. Acad. Sci. 109: 127-167

Goreau, T F., Goreau, N. I. (1959). The physiology of skeleton formation in corals. II. Calcium deposition by hermatypic corals under various conditions in the reef. Biol. Bull. mar. biol. Lab., Woods Hole 117: 239-250

Goreau, T. F., Goreau, N. I. (1960). The physiology of skeleton formation in corals. III. Calcification rate as a function of colony weight and total nitrogen content in the reef coral Manicina areolata (Linnaeus). Biol. Bull. mar. biol. Lab., Woods Hole 118: 419-429

Goreau, T. F., Hartman, W D. (1963). Boring sponge as controlling factors in the formation and maintainance of coral reets. Proc, Am. Ass. Advmt Sci. 75: 25-54

Goren, M. (1979). Succession of benthic community on artificial substratum at Eilat (Red Sea). J. exp. mar. Biol. Ecol. 38: $19-40$

Grigg, R. W., Maragos, J. E. (1974). Recolonisation of hermatypic corals on submerged lava flows in Hawaii. Ecology 55 : $387-395$

Horn, H. S. (1971). The adaptive geometry of trees, Princeton University Press, New Jersey

Lamberts, A. E. (1978) Coral growth: alizarin method. In: Stoddart, D. R., Johannes, R. E. (eds) Coral reefs: research methods. UNESCO, Paris, pp. 523-527

Lang, J. (1973). Interspecific aggression by scleractinian corals. 2. Why the race is not only to the swift. Bull. mar. sci. 23: $260-279$

Loya, Y (1972). Community structure and species diversity of hermatypic corals at Eilat, Red Sea. Mar. Biol. 13: 100-123

Loya, Y (1976a). Recolonisation of Red Sea corals affected by natural catastrophes and man made perturbations. Ecology $57: 280-289$

Loya, Y (1976b). The Red Sea coral Stylophora pistillata is an $r$ strategist. Nature, Lond. 259: 478-480

Loya, Y., Slobodkin, L. B (1.971). The coral reefs of Eilat (Gulf of Eilat, Red Sea). In: Stoddart, D. R., Yonge, C. M. (eds) Regional variation in Indian Ocean coral reefs (Symp. zool. Soc. Lond. 28). Academic Press, London, pp. 117-139

Pichon, M. (1978a). Recherches sur les peuplements à dominance d'anthozoaires dans les récifs coralliens de Tuléar (Madagascar). Atoll. Res. Bull. 222: p. XXXV, 447

Pichon, M. (1978b). Problems of measuring and mapping coral reef colonies. In: Stoddart, D. R., Yonge, C. M. (eds) Coral reefs: research methods. UNESCO, Paris, pp. 219-230

Porter, J. W. (1972). Patterns of species diversity in Caribbean reef corals. Ecology 53: 745-748

Porter, J. W (1974). Community structure of coral reefs on opposite sides of the Isthmus of Panama. Science, N. Y 186: $543-545$ 
Porter, J. W. (1976). Autotrophy, heterotrophy and resource partitioning in Caribbean reef-building corals. Am. nat. 110:731-742

Riedl, R. (1971). Water movement: general introduction. In: Kinne, O. (ed.) Marine ecology, Vol. I, Environmental factors, Part 2. Wiley, London, pp. 1085-1089

Riedl, R. (1972). Water movement: animals. In: Kinne, O. (ed.) Marine ecology, Vol. I, Environmental factors, Part 2. Wiley, London, pp. 1123-1156

Rosen, B. R. (1971). Principal features of reef coral ecology in shallow water environments of Mahe, Seychelles. In: Stoddart, D. R., Yonge, C. M. (eds) Regional variation in Indian Ocean coral reefs (Symp. zool. Soc. Lond. 28). Academic Press, London, pp. 163-183

Rosen, B. R. (1975). The distribution of reef corals. Rep Underwater Ass. 1: 1-16

Rosen, B. R. (1977). The depth distribution of recent hermatypic corals and its palaeontological significance. Mém. Bur. Rech. Géol. minèr. 89: 507-517

Scheer, G. (1972). Investigations of coral reefs in the Maldive Islands with notes on lagoon patch reefs and the method of coral sociology. Proc. Symp. corals and coral reefs (1969) Mar. biol. Ass. India, 1972: 87-120

Scheer, G. (1978). Application of phytosociological methods. In: Stoddart, D. R., Johannes, R. E. (eds) Coral reefs: research methods. UNESCO, Paris, pp. 175-196

Sheppard, C. R. C. (1979). Interspecific aggression between reef corals with reference to their distribution. Mar. Ecol. Prog. Ser. 1: 237-247

Sheppard, C. R. C. (in press). Reef and soft substrate coral fauna of Chagos, Indian Ocean. J. nat. Hist.
Sheppard, C. R. C., Jupp, B. P., Sheppard, A. L. S., Bellamy, D J. (1978). Studies on the growth of Laminarja hyperborea (Gunn) Fosl. and Laminaria ochroleuca Pyl. on the French channel coast. Bot. mar XXI: 109-116

Stephenson, T. A., Stephenson, A. (1933). Growth and asexual reproduction in corals. Scient Rep. Gt Barrier Reef Exped. 3: $167-217$

Stimson, J. S. (1978). Mode and timing of reproduction in some common hermatypic corals of Hawaii and Enewetak. Mar Biol. 48: 173-184

Stoddart, D. R. (1973). Coral reefs of the Indian Ocean. In: Jones, O. A., Endean, R. (eds) Biology and geology of coral reefs, Vol. 1. Academic Press, London, pp. 51-91

Stoddart, D. R., Yonge, C. M. (eds) (1971). Regional variation in Indian Ocean coral reefs (Symp. zool. Soc. Lond. 28), Academic Press, London

Tamura, T., Hada, Y. (1932). The growth rate of reef building corals inhabiting the South Sea islands. Tohaku Imp. Sci. Rep. 7: 433-455

Taylor, J. D. (1968). Coral reefs and associated invertebrate communities (mainly molluscan) around Mahe, Seychelles. Phil. Trans. Roy. Soc. (B) 254: 129-206

Wells, J. W. (1954). Recent corals of the Marshall Islands, Bikini and nearby atolls. U.S. geol. surv. pap. 260 (1): 385-486

Wells, J. W. (1956). Scleractinia. In: Moore, R. C. (ed.) Treatise on invertebrate palaeontology. Univ. Kansas \& Geol. Soc. Am. Press, Part F, pp. 328-444

Yonge, C. M. (1963). The biology of coral reefs. In: Russell, F. $\mathrm{S}$. (ed.) Advances in marine ecology. Academic Press, London, pp. 209-260 